\title{
PENGARUH BEBERAPA EKSTRAK TUMBUHAN TERHADAP DEIGHTONIELLA TORULOSA SYD. ELLIS PENYEBAB PENYAKIT UJUNG HITAM BUAH PISANG
}

\author{
Joko Prasetyo $^{1}$ dan Efri ${ }^{1}$
}

\begin{abstract}
The effect of some plant extracts on Deightoniella torulosa Syd. Ellis the causative agent of black tip disease of banana. An experiment was conducted to evaluate the effect of some plant extracts on the growth and reproduction of Deightonella torulosa. The plants used in this experiments were Zingiber cassumunar, Acorus calamus, and Amomum cardamomum. The treatments of the factorial $(3 \times 4)$ experiment were arranged in a completely randomized design with three replicates. The first factor (plant extracts) consisted of Z. cassumunar, A. calamus, and A. cardamomum extracts. The second factor (extract concentration) consisted of $0,100,200$, and $300 \mathrm{mg} / \mathrm{l}$. Variables examined were the colony diameter and conidial density of $D$. torulosa. The result of the experiment shows that extract of $Z$. cassumunar, A. calamus, and A. cardamomum extracts suppressed fungal colony diameter. On Z. cassumunar and A. calamus extracts, the higher the concentration the higher fungal colony diameter suppressed. The most effective suppression by the extract was at 300 $\mathrm{mg} / \mathrm{l}$. A. calamus extract was more effective than Z. cassumunar and A. cardamomum at $100 \mathrm{mg} / \mathrm{ml}$. Z. cassumunar and A. calamus extracts had the same effectivity at $200 \mathrm{mg} / \mathrm{l}$, and both was more effective compared to A. cardamomum. $Z$. cassumunar was more effective compared to $A$. calamus and $A$. cardamomum at $300 \mathrm{mg} / \mathrm{l}$. The results of the experiment also showed that Z. cassumunar, A. calamus, and A. cardamomum suppressed conidial production of D. torulosa. Z cassumunar most effectively suppressed conidia production at $300 \mathrm{mg} / \mathrm{l}$. A. calamus extract suppressed conidial production the most effectively at 200 and $300 \mathrm{mg} / \mathrm{l}$. A. cardamomum extract significantly suppressed conidia production only at $300 \mathrm{mg} / \mathrm{l}$. Z. cassumunar and A. calamus extracts were more effective to suppress conidia production compared to A. cardamomum for all level of concentration except control. The effectivity of $Z$. cassumunar and A. calamus was the same at 100 and $300 \mathrm{mg} / \mathrm{l}$. Z. cassumunar extract was more effective than A. calamus at $200 \mathrm{mg} / \mathrm{l}$.
\end{abstract}

Key words: black tip disease, Deightoniella torulos, plant extracts

\section{PENDAHULUAN}

Kendala utama dalam ekspor pisang adalah bercak buah yang salah satu penyebabnya dahulu disebut Helminthosporium torulosum (Wardlaw, 1935). Nama terbaru untuk jamur tersebut adalah Deightoniella torulosa (Miller \& Polard, 1976). D. torulosa pada pisang secara khusus menyebabkan gejala khas berupa bercak hitam pada daerah sekitar ujung buah. Penyakit ini ditemukan pertama kali di perkebunan pisang Cavendish di Bermuda (Wardlaw, 1935). Saat ini jamur tersebut juga menyerang perkebunan pisang PT Nusantara Tropical Fruit di Lampung.

Pengendalian penyakit yang biasa dilakukan adalah dengan fungisida sintetis. Dengan semakin terungkapnya dampak negatip fungisida sintetis, maka banyak usaha pengendalian penyakit diarahkan pada penggunaan teknik yang ramah lingkungan.
Penggunaan bahan-bahan nabati merupakan salah satu alternatif yang menjanjikan.

Beberapa penelitian menunjukkan, bahwa penggunaan bahan nabati dapat menekan perkembangan penyakit. Mukhlis (2000) melaporkan beberapa bahan nabati dapat digunakan untuk menekan penyakit blas pada padi. Ginting et al. (2000) menyatakan bahwa beberapa tepung tumbuhan dapat menekan pertumbuhan Phytophthora capsici secara in vitro.

Beberapa jenis tumbuhan memiliki senyawa kimia seperti minyak atsiri dan terpen dapat berperan sebagai bakterisida dan fungisida (Guenther, 1987). Rimpang jeringau mengandung senyawa nabati seperti asaron, kalamenol, kalamin, kalameon, dan metil eugenol. Rimpang bangle mengandung sineol, pinnen, seskuiterpen, damar lunak pahit, gom, lemak, gula, mineral, albuminoid dan asam-asam organik. Kapulaga mengandung terpineol, terpinil asetat,

${ }^{1}$ Dosen Jurusan Proteksi Tanaman, Fakultas Pertanian, Universitas Lampung 
sineol, borneol dan kamfer (Santoso, 1988). Di antara senyawa-senyawa tersebut diduga ada yang memiliki sifat menghambat pertumbuhan dan reproduksi $D$. torulosa.

\section{BAHAN DAN METODE}

Percobaan dilakukan di Laboratorium Penyakit Tanaman Jurusan Proteksi Tanaman Fakultas Pertanian Universitas Lampung pada bulan Januari sampai Maret 2000. Perlakuan disusun secara faktorial (3 x 4) dalam rancangan acak lengkap dengan tiga ulangan. Faktor I adalah jenis ekstrak, yaitu bangle, jeringau, dan kapulaga. Faktor II adalah konsentrasi ekstrak, yaitu 0 mg/l, $100 \mathrm{mg} / \mathrm{l}, 200 \mathrm{mg} / \mathrm{l}$, dan 300 $\mathrm{mg} / \mathrm{l}$.

D. torulosa ditanam pada media secara food poisoned technique. Pengamatan dilakukan terhadap pertumbuhan dan reproduksi $D$. torulosa. Peubah pertumbuhan adalah jari-jari koloni dan peubah reproduksi adalah kerapatan konidia yang ditentukan dengan hemasitometer. Data yang diperoleh diolah secara statistik dengan sidik ragam; perbedaan nilai tengah diuji dengan uji beda nyata terkecil; dan keragaman data diuji dengan uji Bartlett. Semua pengujian tersebut dilakukan pada taraf nyata 5\%.

\section{HASIL DAN PEMBAHASAN}

Hasil percobaan menunjukkan, bahwa ekstrak bangle, jeringau, dan kapulaga dapat menekan pertumbuhan (jari-jari koloni) D. torulosa secara nyata (Tabel 1). Penekanan secara nyata terjadi mulai pada konsentrasi $100 \mathrm{mg} / \mathrm{l}$ untuk bangle dan jeringau, sedangkan untuk kapulaga mulai konsentrasi 200 mg/l. Pada bangle semakin tinggi konsentrasi penekanan terhadap jari-jari koloni semakin kuat.

Tabel 1. Pengaruh jenis ekstrak tumbuhan dan tingkat konsentrasi terhadap jari-jari koloni D. torulosa pada pengamatan $7 \mathrm{hst}$

\begin{tabular}{cccc}
\hline $\begin{array}{c}\text { Taraf konsentrasi } \\
(\mathrm{mg} / \mathrm{l})\end{array}$ & Bangle & $\begin{array}{c}\text { Jari-jari koloni }(\mathrm{mm}) \\
\text { Jeringau }\end{array}$ & Kapulaga \\
\hline 0 & 36,33 a & 35,00 a & 34,33 a \\
& A & A & A \\
100 & $25,33 \quad$ b & $11,33 \quad$ c & 31,67 a \\
& B & B & AB \\
200 & $8,33 \quad$ b & $9,00 \quad$ b & 30,33 a \\
& C & BC & B \\
300 & $5,33 \quad$ c & 7,00 b & 30,33 a \\
& D & C & B \\
\hline
\end{tabular}

Keterangan: angka dalam tabel yang diikuti oleh huruf yang sama tidak berbeda nyata (uji BNT, $\alpha=0,05$ ). Huruf kecil dibaca ke arah horisontal, sedangkan huruf kapital dibaca ke arah vertikal.

Pada semua tingkat konsentrasi ekstrak kapulaga mempunyai efektivitas yang paling rendah dalam menekan D. torulosa Pada konsentrasi $100 \mathrm{mg} / \mathrm{l}$ ekstrak jeringau lebih efektif menekan jari-jari koloni D. torulosa dibandingkan dengan bangle. Pada konsentrasi $200 \mathrm{mg} / \mathrm{l}$ ekstrak bangle dan jeringau mempunyai efektivitas yang sama. Bangle mempunyai efektivitas paling tinggi pada konsentrasi $300 \mathrm{mg} / \mathrm{l}$.

Tertekannya pertumbuhan D. torulosa disebabkan oleh adanya beberapa senyawa antimikrobia yang ada dalam ekstrak tumbuhan. Pada bangle tampaknya senyawa ini semakin tinggi konsentrasinya dengan semakin tingginya ekstrak tumbuhan. Pada jeringau peningkatan konsentrasi dari $100 \mathrm{mg} / \mathrm{l}$ menjadi $200 \mathrm{mg} / \mathrm{l}$ tidak memberikan pengaruh yang nyata. Hal ini kemungkinan disebabkan oleh adanya senyawa penghambat kerja senyawa antimikrobia, sehingga baru pada peningkatan konsentrasi menjadi $300 \mathrm{mg} / \mathrm{l}$ penekanan terhadap $D$. torulosa meningkat nyata. Kapulaga diperkirakan memiliki kandungan senyawa anti mikrobia yang paling rendah dibandingkan dengan bangle dan jeringau. Hasil percobaan juga menunjukkan, bahwa ekstrak bangle, jeringau dan 
kapulaga dapat menekan produksi konidia oleh D. torulosa (Tabel 2).

Tabel 2. Pengaruh jenis dan konsentrasi ekstrak tumbuhan terhadap kerapatan konidia D. torulosa

\begin{tabular}{|c|c|c|c|c|c|c|}
\hline \multirow{2}{*}{$\begin{array}{l}\text { Taraf konsentrasi } \\
(\mathrm{mg} / \mathrm{l})\end{array}$} & \multicolumn{6}{|c|}{ Kerapatan konidia (x $\left.10^{4} / \mathrm{ml}\right)$} \\
\hline & \multicolumn{2}{|l|}{ Bangle } & \multicolumn{2}{|c|}{ Jeringau } & \multicolumn{2}{|c|}{ Kapulaga } \\
\hline \multirow[t]{2}{*}{0} & 7,67 & $\mathrm{a}$ & 5,33 & $\mathrm{ab}$ & 4,33 & $\mathrm{~b}$ \\
\hline & A & & A & & A & \\
\hline \multirow[t]{2}{*}{100} & 1,33 & b & 1,33 & $\mathrm{~b}$ & 4,67 & $\mathrm{a}$ \\
\hline & B & & $\mathrm{B}$ & & A & \\
\hline \multirow[t]{2}{*}{200} & 1,33 & $\mathrm{~b}$ & 0,33 & C & 6,67 & $\mathrm{a}$ \\
\hline & B & & $\mathrm{C}$ & & A & \\
\hline \multirow[t]{2}{*}{300} & 0,33 & b & 0,00 & b & 2,00 & $\mathrm{a}$ \\
\hline & $\mathrm{C}$ & & C & & B & \\
\hline
\end{tabular}

Keterangan: angka dalam tabel yang diikuti oleh huruf yang sama tidak berbeda nyata (uji BNT, $\alpha=0,05$ ). Huruf kecil dibaca ke arah horisontal, sedangkan huruf kapital dibaca ke arah vertikal.

Pada ekstrak bangle dan jeringau penekanan produksi konidia D. torulosa mulai terjadi pada konsentrasi 100 mg/l, sedangkan pada ekstrak kapulaga penekanan produksi konidia terjadi pada konsentrasi $300 \mathrm{mg} / \mathrm{l}$. Pada ekstrak bangle konsentrasi $300 \mathrm{mg} / \mathrm{l}$ secara nyata lebih efektif dibandingkan dengan konsentrasi yang lebih rendah, sedangkan pada ekstrak jeringau konsentrasi $200 \mathrm{mg} / \mathrm{ml}$ lebih efektif dibandingkan dengan konsentrasi $100 \mathrm{mg} / \mathrm{l}$, tetapi tidak berbeda nyata dengan konsentrasi $300 \mathrm{mg} / \mathrm{l}$.

Pada konsentrasi, baik 100, 200, maupun 300 mg/l ekstrak kapulaga mempunyai efektivitas yang paling rendah dalam menekan produksi konidia $D$. torulosa dibandingkan dengan ekstrak bangle dan jeringau. Pada konsentrasi 100 dan 300 mg/l ekstrak bangle dan jeringau mempunyai efektivitas yang sama, sedangkan pada konsentrasi 200 mg/l jeringau lebih efektif dari pada bangle.

Kemampuan menekan produksi konidia jamur terutama ditentukan oleh kandungan senyawa nabati, yang dapat menghambat proses produksi konidia. Pada kapulaga tampaknya senyawa tersebut kandungannya rendah, sehingga efektivitas baru terlihat pada konsentrasi ekstrak 300 mg/l, pada bangle dan jeringau efektivitas sudah terlihat mulai konsentrasi $100 \mathrm{mg} / \mathrm{l}$. Pada bangle untuk konsentrasi $200 \mathrm{mg} / \mathrm{l}$ efektivitasnya optimal, penambahan konsentrasi menjadi $300 \mathrm{mg} / \mathrm{l}$ secara nyata tidak meningkatkan efektivitas. Hal ini memberikan petunjuk bahwa ada keterlibatan senyawa lain yang pada konsentrasi ekstrak 300 mg/l berada pada level mampu menghambat proses produksi konidia.

\section{SANWACANA}

Penulis menyampaikan terimakasih kepada Saudara Tuti Juniaty, S.P. yang telah membantu pelaksanaan penelitian ini.

\section{DAFTAR PUSTAKA}

Ginting, C., D.R.J. Sembodo, H. Susanto, \& M.P. Yufdi. 2000. Kemampuan beberapa tepung tumbuhan dalam menekan pertumbuhan Phytopthora capsici dari tanaman lada. Hlm. 512-518 dalam Prosiding Kongres Nasional XV dan Seminar Ilmiah PFI Purwokerto, 16-18 September 1999. .

Guenther, E. 1987. Minyak Atsiri. Jilid I. Universitas Indonesia Press, Jakarta.

Miller, P.R. \& H. Pollard. 1976. Multilingual Compendium of Plant Disease. The American Phytopathological Society, St. Paul. 
Mukhlis, H. 2000. Kajian penggunaan ekstrak tumbuhan dalam pengendalian penyakit blas pada padi. Hlm. 63-68 dalam Prosiding Kongres Nasional XV dan Seminar Ilmiah PFI Purwokerto, 16-18 September 1999.
Santoso, B.H. 1988. Kapulaga. Kanisius, Yogyakarta.

Wardlaw, C.W. 1935. Diseases of Banana of the Manila Themp Plant. McMillan and Co., London. 